\title{
Cross-border Financial Intermediation in the European Union, Slovakia and Czech Republic
}

DOI 10.18267/pr.2021.krn.4816.18

\author{
Andrea Slezáková ${ }^{1}$ - Peter Jedinák ${ }^{2}$ \\ ORCID iD: not available ${ }^{1}$, 0000-0002-9030-01832 \\ andrea.slezakova@euba.sk, peter.jedinak@flaw.uniba.sk \\ ${ }^{1}$ University of Economics in Bratislava, Faculty of Commerce, Department of Business \\ Law, \\ Bratislava, Slovakia \\ ${ }^{2}$ Comenius University, Faculty of Law, Financial Law Department, \\ Bratislava, Slovakia
}

\begin{abstract}
The paper discusses the sectoral regulatory framework for distribution (intermediation) of financial services under the EU framework (most notably IDD and Mortgage Credit Directive) and how it is implemented into Slovak integrated (cross-sectoral) regulatory regime for financial intermediation. The notable feature of Slovak regime is that it regulates financial intermediation in all main financial sectors (deposit taking, lending including mortgage and consumer loans, capital markets, insurance, pensions) under common framework. However, the harmonisation through EU law and consequent benefits of the single passport are limited to the distribution of insurance and mortgage loans. The paper further compares the Slovak regime with Czech approach with the aim to investigate potential benefits or risks of the further harmonisation of the regulation of financial intermediation / distribution and also financial advisory across various sectors of the national and wider EU financial market. On one hand, further integration may help creating more sophisticated and complex distribution platforms across the EU benefiting from the single passport. On the other hand, it is questionable whether the Slovak approach can be successfully replicated at the EU level.
\end{abstract}

Keywords: financial intermediation, single passport

JEL Classification codes: G2, K22, K23

\section{INTRODUCTION}

Since the end of the 20th century, a transformation of the way of selling financial services can be seen. The 1990s are associated with a major change in the focus that has shifted from service to client; these development trends have their roots in globalization and increased competition (Klöckner, 2014). When searching for a suitable financial service, the client incurs transaction costs and financial intermediation or financial advisory may be used to reduce them.

Slovak Act No. 186/2009 Coll. On Financial Intermediation and Financial Advisory supplementing and amending other laws as amended (herein after only "Financial Intermediation Act") is reflecting the idea of creating equal conditions for performing distribution of financial services in various sectors of the financial market. The Financial Intermediation Act has unified the conditions for the provision of financial intermediation and financial advisory in the area of financial services in the sectors insurance or reinsurance, capital market, supplementary pension savings, granting loans, housing loans and consumer loans, acceptance of deposits and old-age pension savings. In this context, it must be 
emphasized that this is a unique piece of legislation and a way of regulation that we do not find in neighbouring countries.

Integrated regulation of financial intermediation and financial advice in various sectors does not exist in European Union law, which is characterized by a sectoral approach which, moreover, is not fully interconnected and harmonized, even in directly related areas such as the distribution of financial instruments (according to MiFIDII) and insurance-based investment products (according to IDD).

Reflecting on the single passport concept of the EU law, the Financial Intermediation Act enables a financial intermediary from another Member State in the area of housing loans and a financial intermediary from another Member State within the insurance and reinsurance sector to provide financial intermediation or financial advisory in Slovakia. Similarly, Slovak financial intermediaries in these sectors benefit from the same regime when providing the services from Slovakia. This is the outcome of implementing directives, which are reflecting the single-passport principle.

The Financial Intermediation Act also however imposes strict prudential and conduct of business requirements on financial intermediaries in other sectors of the financial market as well (lending, deposit taking and pension funds), however without the potential benefit of the single passport.

\section{LITERATURE REVIEW}

With regard to key concepts of EU law, relevant theoretical background pertains mainly to the nature of EU legislation instruments and the concept of single passport.

A directive is binding on each member state to which it is addressed as to the result to be achieved, but leaves the choice of form and means to the national authorities (Haratsch et al, 2018 , p. 175). This enables the member states to implement the directive taking into account their national characteristics (Fisher et al, 2020, p. 625) The directive is the classic instrument for the harmonization of national legal provisions through the approximation of content, since it leaves the member states a certain degree of leeway in the implementation, the directive presents itself as the gentler measure compared to the regulation (Herdegen, 2018, p. 196).

The discretion of the member states comes into play in particular in cases in which the national legislature exceeds the minimum provisions when implementing the directive (Haratsch et al, 2018 , p. 176). However, since directives often contain very detailed regulations, the national legislature is increasingly limited to replicating the European requirements (Hobe, 2014, p. 95). This is even more true where the directive provides for a so called "maximum harmonization" or is supplemented by implementing EU regulations or delegated regulations, which effectively prevents the member states from developing own approach on detailed aspects which are left open under a directive (see for example the complex of EU legislation related to MiFIDII).

With regard to the quality of the act of implementation, the ECJ initially demanded in general that the member states, when choosing the form and means, should take those most suitable for ensuring the practical effectiveness of the directives. Member states must therefore transpose the directive into binding national provisions that meet the requirements of legal certainty and legal clarity (Streinz, 2012, p. 168).

Cross-border activities of financial institutions in the EU are based on two out of the four fundamental freedoms - the free movement of persons and the free provision of services (Pénzeš, 2013). 
A large number of activities in the European financial market are subject to licensing requirements. If a license had to be obtained for each member state, this would mean a great deal of effort and correspondingly high costs for the service provider (Imm, 2020, p. 71). For this reason, the EU law provides for the single passport. Once a license has been obtained in the home member state, it is also authorized to sell financial instruments and products throughout the EEA without the need for an individual license in each other country (Imm, 2020, p. 71).

With regard to Slovak law, the main literature used in this paper is the commentary on the Financial Intermediation Act (Slezáková et al, 2020). The commentary discusses inter alia with implementation of Directive (EU) 2016/97 on insurance distribution (recast) (hereinafter "IDD") and Directive 2014/17/EU on credit agreements for consumers relating to residential immovable property (hereinafter the "Mortgage Credit Directive") and how these are reflecting the single-passport principle. The commentary also reflects the impact of Directive 2014/65/EU on markets in financial instruments (hereinafter "MiFIDII").

Finally, with regard to Czech law, the authors have used the commentary on Czech Act on Undertaking in Capital Markets (Husták et al, 2012), articles on the Czech financial intermediation regime in general (Šárek, 2012, Šindelář and Erben, 2017) as well as public information provided by the Czech Ministry of Finance.

\section{METHODOLOGY}

The method of analysis will be used in order to obtain relevant information. The analysis is based on the assumption that the knowledge of the whole begins with the knowledge of its individual parts. The aim of the analysis as a method is therefore to mediate the knowledge of the whole through the knowledge of its individual parts.

It can be distinguished between factual and legal analysis. In the factual analysis, the important facts (parts) are being isolated from the unimportant ones, thus creating an idea of the factual state (whole). The aim of legal analysis is to obtain a basis for meaningful argumentation that will support the legal conclusion.

Further, the comparative method will be used. The essences of the comparison are thought operations by which the similarity is being examined or difference between the examined elements and we try to reveal the causes of these similarities, resp. differences. In case of this paper, the comparisons will be made between the general EU legal framework, Czech legal framework and Slovak legal framework governing the financial intermediation.

In addition to the comparative method, the paper explores historical context of the legislation at EU and national level in order to identify and justify existing differences in the approach of these legislations.

Finally, in terms of concepts and terminology, we perceive the "financial intermediation" both through general meaning of that term, but also through the legal definition under the Financial Intermediation Act. In general sense, financial intermediation is equivalent of "distribution" of insurance, financial instruments, mortgage credits or other financial services or products. Hence the term "insurance distribution" under the IDD. In narrower sense of legally defined term under the Financial Intermediation Act, the financial intermediation is a regulated activity of a licensed agent on behalf of a financial institution (principal) consisting largely of solicitation and entering into a financial contract between the financial institution and a client. The financial intermediation in this sense includes ancillary activities such as provision of advice to the client and management of client's requests or claims in relation to the financial service ( $\S 2$ of the Financial Intermediation Act, Slezáková et al, 2020, p. 41). 


\section{RESULTS AND DISCUSSION}

This main chapter is divided into three parts discussing the details of EU law position, Slovak law position and Czech law position concerning the financial intermediation.

\subsection{European law position}

The EU law position on the regulation of the financial intermediation in general sense is fragmented and driven by sectoral developments in various segments of the financial markets. There are various motivations and driving forces behind the development of this EU sectoral legislation, which consists of IDD, Mortgage Credit Directive and MiFIDII.

\section{Insurance sector}

In the insurance sector covered by IDD, the EU law is the oldest, dating back over 50 years, with the first directive in this area being Council Directive 64/225/EEC on the abolition of restrictions on freedom of establishment and freedom to provide services in respect of reinsurance and retrocession. A first step to facilitate the exercise of freedom of establishment and freedom to provide services for insurance agents and brokers was made by Council Directive 77/92/EEC on measures to facilitate the effective exercise of freedom of establishment and freedom to provide services in respect of the activities of insurance agents and brokers (Recital 2 of Directive 2002/92/EC).

Traditionally, the insurance sector relied heavily on various intermediaries, agents, brokers or distributors. Given the nature of insurance business, it is relatively easy to distinguish between the insurance itself, which in simple terms represents an assumption of certain risk by an insurance company in exchange for a premium paid by a client, and on the other hand the distribution of insurance, which is relatively simple process of brokerage of an insurance contract. There is rarely a complex layered distribution structure and this simple model largely remains typical in the non-life insurance segment to the present days. In life insurance, the position has become more complex with development of investment based insurance products, which are also the main driver for increasing complexity of the regulation of insurance distribution resulting in enactment of IDD.

From very early times, the EU law supported cross-border insurance distribution and the concept of single passport as the mean of establishment of single EU insurance market and necessary instrument of achieving the freedom of establishment and freedom to provide services in this area.

\section{Mortgage loans sector}

In the mortgage loan sector covered by Mortgage Credit Directive and its provisions concerning the credit intermediaries, the historic situation is widely different. The EU law in this area is relatively novel and is reaction to the financial crisis in 2007 - 2009. One of the aims of the Mortgage Credit Directive is to create a single EU market for mortgage loans - the aim, which is largely still far away, given that the mortgage loans markets are still significantly fragmented in the EU, with few lenders acting extensively outside of their home markets and few borrowers seeking credit outside of their country of residence. According to the European Commission, the share of consumers who have already purchased banking products from another Member State was less than $3 \%$ for credit cards, current accounts and mortgages and only $5 \%$ of consumer loans had been obtained cross-border (European Commission, 2015).

But the Mortgage Credit Directive is not primarily (or only) concerned with facilitation of the single market and the exercise of the freedom of establishment and freedom to provide services. As summarized in the Mortgage Credit Directive itself, a series of problems have been 
identified in mortgage markets within the EU relating to irresponsible lending and borrowing and the potential scope for irresponsible behaviour by market participants including credit intermediaries and non-credit institutions. Those problems are driven by market and regulatory failures as well as other factors such as the general economic climate and low levels of financial literacy. Other problems include ineffective, inconsistent, or non-existent regimes for credit intermediaries and non-credit institutions providing credit for residential immovable property. The problems identified have potentially significant macroeconomic spill-over effects, can lead to consumer detriment, act as economic or legal barriers to cross-border activity and create an unlevel playing field between actors (Recital 4 of the Mortgage Credit Directive).

Thus the drivers behind the EU law regulation of the mortgage credit intermediaries is not only to support the single market and to achieve a higher level of consumer protection, but also to address the macroeconomic effects of irresponsible lending in individual member states, as such irresponsible practices in one member state may affect the EU as whole. The concept of single passport for the mortgage credit intermediation has to be considered in this broader context.

\section{Investment services}

Finally, the EU regulation of investment services is relatively recent compared to the insurance regulation, although certainly predating the post-crisis generation of the financial regulation. The first EU legislation in this area was Directive 93/22/EEC of 10 May 1993 on investment services in the securities field (hereinafter "ISD"), establishing the concept of "investment firms" and the single passport for such firms. However under the ISD and then under the first MiFID Directive and also under the current MiFIDII, the distinction between the "main service providers" and their "distributors" has been never fully recognised. That is because the investment firms were often and largely intermediaries per se and large aspects of the investment services are in fact intermediation by their nature. Hence the historical designation of the investment firms as "brokers". Also, in investment services, there are complex chains of intermediaries such as when a client gives an order to buy securities to its local broker, the local broker transmit the order to a broker on stock-exchange (often through other intermediary brokers), the trade is executed on the exchange and the purchased securities are delivered to the client's account held with local custodian through a chain of other custodians. In this multiple layer structure it is difficult to clearly see classic principal / agent relationships between the different service providers. Rather the whole market acts as a chain or net of intermediaries.

In this context it is not surprising that MiFIDII does not recognise a single passport of "investment services intermediaries" as special subcategory. Rather it grants a single passport only to "investment firms" on the understanding that some of their activities (e.g. execution or transmission of orders) are in fact intermediation by nature.

That being said, MiFIDII does recognise that some member states may have historically established concepts of "limited investment service providers", whose activities are limited to relatively narrow area or reception and transmission of client orders and certain ancillary services. That is why MiFIDII include an exemption that member states may choose not to apply MiFIDII to any persons for which they are the home member state, provided that the activities of those persons are authorised and regulated at national level and those persons: (a) are not allowed to hold client funds or client securities and which for that reason are not allowed at any time to place themselves in debit with their clients; (b) are not allowed to provide any investment service except the reception and transmission of orders in transferable securities and units in collective investment undertakings and/or the provision of investment advice in relation to such financial instruments; and at the same time (c) in the course of providing that service, are allowed to transmit orders only to licensed investment firms, credit 
institutions, collective investment undertakings or certain other authorised entities (Article 3(1) of MiFIDII).

However, these exempt firms must be subject to MiFIDII analogous authorisation and ongoing supervision, conduct of business obligations and organisational requirements and must be covered by an investor-compensation scheme or professional indemnity insurance (Article 3(2) of MiFIDII). At the same time, these exempt firms shall not benefit from single passport regime (Article 3(3) of MiFIDII).

It follows that such exempt intermediation firms are in fact subject to "at least analogous" burden of compliance with the bulk of MiFIDII requirements as regards the authorisation, ongoing supervision, conduct of business and governance. However, such stringent regulation and supervision does not bring them the benefit of the single passport.

For completeness, MiFIDII also recognises the concept of a "tied agent". However, a tied agent can only transmit orders to single investment firm (hence it is "tied"). We do not consider this concept to be a functional equivalent of financial intermediation in the investment services sector.

\section{Other sectors of financial intermediation}

There is no comprehensive EU regulation of financial intermediation of other segments of the financial market. That means there is no harmonisation of the distribution or intermediation with regard to deposit taking, lending (other than mortgage credits), pension funds, payment services or other financial services.

\section{Financial advisory on an independent basis}

By "financial advisory on an independent basis" we understand advice provided for consideration payable solely by the client and not in the context of distribution of a financial or investment product where the commission to the agent is paid by the financial institution (hence such advice is provided on a "non-independent basis"). There is no comprehensive EU regulation of financial advisory on an independent basis, except for investment advice regulation under MiFIDII. However, under MiFIDII, the investment advice is one of the main investment services requiring a full MiFIDII authorisation. For completeness, the insurance distribution under IDD includes "activities of advising on" contracts of insurance (Article 2(1) of IDD). This however implies that the advice is an element of insurance distribution and not an independent service.

\subsection{Slovak law position}

In connection with the entry the European Union in 2004, Slovakia had to quickly implement a number of existing EU directives in the financial sector, including MiFIDI (later recasted as MiFIDII) and Directive 2002/92/EC (later recasted as IDD). These transpositions followed the sectoral fragmentation of the EU law as described above, i.e. they were included in separate statutes.

\section{Integrated approach}

However, Slovakia has adopted the Financial Intermediation Act relatively early thereafter in 2009. The aim of this legislation was to modernize previous legislation for financial intermediation providers as well as the entry of new entities into the financial market in defined sectors (insurance or reinsurance, capital markets, lending, deposit taking and pension funds) and to contribute to the creation of a healthy competitive environment as well as to ensure better protection of the clients in all major sectors of the financial market. Such integrated 
approach is unique in that it brings the financial intermediation in various sectors under the common prudential and conduct of business framework (Slezáková et al, 2020, p. 29).

The Financial Intermediation Act distinguishes the following categories of financial agents: an independent financial agent, a bound financial agent, a subordinate financial agent, a tied agent and a supplementary insurance intermediary.

The Financial Intermediation Act also regulates independent financial advice, in particular the requirement that a financial advisor can accept remuneration solely from its clients, recipients of the advice.

\section{Single passport in action}

Despite the broader scope of the Slovak regulation, the benefit of single passport is inevitably limited to the sectors, in which such a concept is recognised under the EU law. As discussed above, these sectors are limited to insurance distribution and mortgage loans.

As to the operation of the single passport regime, this is implemented in accordance with the rules set out in Articles 4 and 6 of the IDD and equivalent provisions of the Mortgage Credit Directive. In general, in case of outbound services (i.e. intermediation provided from Slovakia as the home member state) the financial intermediary in Slovakia shall provide certain information to the National Bank of Slovakia, including information whether it intends to provide cross-border intermediation via branch (freedom of establishment) or on a pure crossborder basis (freedom to provide services) and information on the scope of the services and products and related organisational requirements. If the National Bank of Slovakia is satisfied with the information provided and relevant requirements, it notifies the competent authority of the host member state within 30 days. The National Bank of Slovakia will also inform the financial intermediary about the notification and the financial intermediary is entitled to commence the activities in the host member state from the date of such notification. These procedures are regulated in Articles 20, 20a and 20b of the Financial Intermediation Act. The process works vice versa in case of inbound services (i.e. intermediation provided into Slovakia as the host member state) as set out in Articles 11, 11a, 11b, 11c and 11d of the Financial Intermediation Act (also Slezáková et al, 2020, p. 90 - 148 with respect to inbound intermediation and p. 217 to 252 with respect to outbound intermediation).

The rules are in fact more complex and include certain intervention rights of the competent authorities of the host member states, but these details are not considered for the purposes of our discussion.

\section{Benefits of and concerns with Slovak regulation}

Slovak integrated approach provides the benefit of comprehensive regulatory framework thus ensuring the level-playing field between different kinds of intermediaries and effectively not allowing for a regulatory arbitrage between various segments. It also imposes single standard of qualification requirements, basic common level of the conduct of business requirements and common supervisory framework. All this should arguably result in improved market integrity and stronger protection of the clients. The benefits of the integrated approach are also noted in Czech literature (Šindelář and Erben, 2017, p. 14).

On the other hand, the Slovak regime is causing some potential concerns, mainly:

- Despite the purported comprehensive single statute approach, the Financial Intermediation Act in fact does refer extensively to sectoral legislation concerning the investment services (Slovak Act 566/2001 Coll. on securities and investment services, as amended), mortgage loans (Slovak Act 90/2016 Coll. on residential loans, as amended) and also insurance regulation (Slovak Act 39/2015 Coll. on insurance activity, as amended). This creates a layered legislative structure, which can be 
ultimately less robust than a set of sectoral legislation because of inherent clarity issues, increased complexity and potential lack of internal coherence.

- In the capital markets (investment services) segment, the Slovak regime relies on exemption under Article 3(1) of MiFIDII. Without full MiFIDII licence, the intermediaries in this regime will be necessarily limited in terms of the scope of their services and will not have any benefit of the single passport. At the same time, they are subject to essentially the same conduct of business and some prudential requirements as investment firms under MiFIDII (Section 37 of the Financial Intermediation Act).

- Despite the benefit of single passport is granted to insurance distributors from another member states, these entities (even if they are established in Slovakia via a branch) cannot use Slovak tied agents, which results in disadvantage of the cross-border insurance distributors in terms of their capacity to build distribution network compared with Slovak domiciled insurance distributors. This is not necessarily a consequence of the integrated approach, but maybe rather a result of an imperfect IDD implementation.

- There is a question of over-regulation. Higher level of regulation and supervision is usually associated with the benefit of single passport. However, Slovak financial intermediaries in the segments of lending (other than mortgage credits), deposit taking and pension savings are subject to more stringent regulation than their counterparts in other member states. At the same time, such incremental regulatory burden is not compensated by the benefit of the single passport, i.e. the ability to provide services on a cross-border basis. Admittedly, the level of regulation is always a matter of particular considerations in the local market and there is no real competitive disadvantage, because Slovak financial intermediaries in non-harmonised sectors are not facing competition of foreign intermediaries in Slovak market. However, it is legitimate to question why some (if not most) member states including the Czech Republic impose less stringent regulatory requirements compared to those applied in Slovakia.

- Finally, the financial advisory under the Financial Intermediation Act is defined solely on an independent basis (i.e. being remunerated exclusively by the client, recipient of the advice). When coupled with strict regulatory and supervisory regime, prohibited combination of provision of the independent advice with distribution and nonindependent advice within single entity (Section 10(1) of the Financial Intermediation Act) and no benefit of single passport, the regulation makes such financial advice prohibitively expensive for the clients and non-attractive for the market participants.

For these reasons,(except for the reason in the second paragraph), it is questionable whether the Slovak approach can be successfully replicated at the EU level or even at the level of national laws of other member states.

\subsection{Czech law position}

The authors are not being qualified in Czech law. It is understood however that the Czech approach to regulation of the financial intermediation is sectoral, i.e. generally following the EU approach of regulation of financial intermediation by specific legislative instruments (laws) in individual segments the financial markets and not under a single framework. 


\section{Insurance sector}

IDD was implemented into Czech law though Act No. 170/2018 Coll. on distribution of insurance and reinsurance. The single passport provisions are largely in line with Articles 4 and 6 of the IDD.

\section{Mortgage loans sector}

Mortgage Credit Directive was implemented into Czech law through Act No. 257/2016 Coll. on consumer loans. This act regulates both standard "consumer loans" and also "residential loans". This is different from Slovak approach, which regulates "consumer loans" and "residential loans" in two separate statutes. Single passport provisions concerning the intermediation of mortgage loans are set out in Sections 46 to 52.

\section{Investment services}

Investment intermediation is regulated in Section 29 of the Act on Undertaking in Capital Market. This reflects the exemption under Article 3(1) of MiFIDII (Husták et al, 2012, p. 303). The approach is similar to regulation of Slovak financial intermediaries in the capital markets segments and largely follows the requirements of MiFIDII. Czech investment intermediaries have no benefit of single passports.

\section{Other sectors}

Other sectors (general lending and deposit taking) are not regulated under Czech law, except for pension savings. As the pension savings and pension funds are largely not harmonised under EU law, there is no benefit of single passport.

\section{Integrated approach in the Czech Republic?}

There was a proposal of new integrated Czech legislation on distribution of financial services in 2012 (Ministry of Finance, 2012), which to large extent resembled the Slovak approach (Šárek, 2012). The current sectoral fragmentation of Czech regulation is also cited as the potential source of regulatory disparities and market stability issues (Šindelár and Erben, 2017, p. 14). However, the proposal of the integrated legislation was abandoned and apparently was not revisited at the government level since 2012.

\section{CONCLUSION}

The summary of our findings in terms of the level of regulation and availability of single passport in relevant segments of financial intermediation is set out in the table below:

Tab. 1 Single passport in relevant segments of financial intermediation

\begin{tabular}{|l|l|l|l|}
\hline & EU law & Czech law & Slovak law \\
\hline $\begin{array}{l}\text { Insurance sector - } \\
\text { regulated / single passport } \\
\text { available? }\end{array}$ & YES / YES & YES / YES & YES / YES \\
\hline $\begin{array}{l}\text { Mortgage loans sector - } \\
\text { regulated / single passport } \\
\text { available? }\end{array}$ & YES / YES & YES / YES & YES / YES \\
\hline $\begin{array}{l}\text { Other loans - } \\
\text { regulated / single passport } \\
\text { available? }\end{array}$ & NO / NO & NO / NO & YES / NO \\
\hline Investment services - & YES / NO & YES / NO & YES / NO \\
\hline
\end{tabular}




\begin{tabular}{|l|l|l|l|}
\hline & EU law & Czech law & Slovak law \\
\hline $\begin{array}{l}\text { regulated / single passport } \\
\text { available? }\end{array}$ & NO / NO & YES / NO & YES / NO \\
\hline $\begin{array}{l}\text { Pension funds distribution - } \\
\text { regulated / single passport } \\
\text { available? }\end{array}$ & NO / NO & NO / NO & YES / NO \\
\hline $\begin{array}{l}\text { Deposit taking - } \\
\text { availated / single passport }\end{array}$ & & & \\
\hline
\end{tabular}

Source: relevant EU and national legislation discussed above

It follows from the above that the benefit of single passport for the financial intermediation in the European Union is limited to the segments of insurance and reinsurance and mortgage loans. At the same time, it is clear that the Slovak integrated approach results in the most stringent regime.

Such more stringent regulation can be (and typically is) outweighed by the benefit of single passport - i.e. the firms accept the higher regulatory burden in exchange for the potential to provide their services on a cross-border basis in more than one member state. However, as discussed in relation to Slovak framework in part 3.1.2 above and also taking into account the different history, methodology and aims of relevant EU directives discussed in part 3.1.1 above, there are significant questions as to whether the Slovak integrated approach could be followed at the EU level.

\section{ACKNOWLEDGEMENT}

This contribution is the result of the project implementation: APVV-16-0553 "Metamorphoses and innovations of the corporations" concept under conditions of globalisation"/,Premeny a inovácie konceptu kapitálových spoločností v podmienkach globalizácie"

\section{REFERENCES}

European Commission (2015)Green paper on retail financial services: Better products, more choice, and greater opportunities for consumers and businesses. Retrieved 17 February 2021, from https://eur-lex.europa.eu/legal-content/EN/TXT/?uri=COM:2015:630:FIN.

Fischer, P., Köck, H., F.,\& Karollus, M. (2002). Europarecht. 4., völlig neu bearbeitete Auflage. Wien: LINDE VERLAG.

Haltern, U. (2017). Europarecht. Band I. 3., völlig überarbeitete und ergänzte Auflage. Tübingen : Mohr Siebeck.

Haratsch, A., Koenig, Ch.,\& Pechstein, M. (2018). Europarecht. 11., überarbeitete und aktualisierte Auflage. Tübingen: Mohr Siebeck.

Herdegen, M. (2018). Europarecht. 20., überarbeitete und erweiterte Auflage. München: C. H. Beck.

Hobe, S. (2014). Europarecht. 8., neu bearbeitete Auflage. München: Verlag Franz Vahlen. Husták, Z., Šovar, J., Franěk, M., Smutný, A., Cetlová, K., \& Doležalová, D. (2012).Zákon o podnikání na kapitálovém trhu. Komentáŕ. 1. vydání. Praha: C. H. Beck. 
Imm, T. (2020). Der finanz- und kapitalmarktrechtliche Gleichwertigkeitsmechanismus. Tübingen : Mohr Siebeck.

Klöckner, B.W. (2014).Systemisch verkaufen und beraten in der Finanzbranche: Dauerhaft erfolgreich durch gelingende Kundenbindung. Springer Gabler : Wiesbaden.

Ministerstvo financií Českej republiky (2012). Věcný záměr zákona o některých podmínkách nabízení, zprostředkování a poskytování finančních služeb a o finančním poradenství (zákon o distribuci finančních služeb). Retrieved 17 February 2021, fromhttps://www.vlada.cz/assets/ppov/Irv/ria/databaze/MF-por-c--9_2012.pdf.

Pénzeš, P. (2013). Právne aspekty cezhraničného podnikania finančných inštitúcií v EÚ. Biatec, 21(4), 28 - 31.

Slezáková, A., Šimonová, J., Jedinák, P. et al (2020).Zákon o finančnom sprostredkovaní. Komentár. Bratislava : Wolters Kluwer.

Streinz, R. (2012)Europarecht. 9., völlig neu bearbeitete Auflage. Heidelberg, München, Landsberg, Frechen, Hamburg: C.F. Müller.

Šárek, R. (2012). Bude Slovensko v oblasti distribuce na finančním trhu dobrým př́kladem pro Českou republiku? Medzinárodné vzt'ahy - Journal of International Relations, 10(1), 76 - 85.

Šindelář, J.\& Erben, M (2017).Problémy v distribuci finančních produktů: selhání trhu anebo regulace? Český finanční a účetní časopis, 12(3), 5-17.https://doi.org/10.18267/j.cfuc.498 